\title{
Note from the editors: Polio - good news and bad news
}

Eurosurveillance editorial team (eurosurveillance@ecdc.europa.eu)1

1. European Centre for Disease Prevention and Control (ECDC), Stockholm, Sweden

Citation style for this article:

Eurosurveillance editorial team. Note from the editors: Polio - good news and bad news. Euro Surveill. 2014;19(7):pii=20704. Available online: http://www. eurosurveillance.org/ViewArticle.aspx?Articleld=20704

Article published on 20 February 2014

It is well known that polio, a vaccine-preventable disease that has afflicted mankind since over a thousand years BC, has been targeted by the World Health Organization (WHO) for eradication [1]. Neither is it news that in the past decades, a worldwide concerted effort has been tremendously successful in reducing the incidence of the disease and interrupting the transmission of wild-type polioviruses (WPV) so that there are only three countries with endemic WPV circulation left, on two continents, namely Afghanistan, Nigeria and Pakistan [2].

In the past 12 months, however, polio has made the headlines around the globe several times. There was good news and bad news. Very sad news was, of course, the killings of several polio workers in Pakistan [3], from where the media reported a new bomb attack on police forces protecting polio vaccinators just a few days ago [4], and about symptomatic cases among children in Syria, a country struck by civil war, in October 2013 [5]. Moreover, there was the introduction and silent transmission of WPV 1 over several months in Israel, first detected in April 2013 [6]. The good news was about a landmark achievement: India, which since 2006 had been among the last four countries with endemic virus circulation, has been free of polio for three years [7] and is expected to be officially certified as 'polio-free' within the coming months [8]. This is evidence for the fact that eradication is possible.

Some difficulties in reaching the eradication goal along with good news are described in the articles in this week's issue of Eurosurveillance. While there was silent transmission in Israel, it was detected early, thanks to a well-functioning environmental surveillance system, and interrupted with a major vaccination effort; the polio outbreak in Tajikistan in 2010, despite exportation to neighbouring countries within a few months, was also stopped through several rounds of supplementary immunisation activities.

We would like to thank all contributors to this special issue on polio for their good collaboration, in particular Jacob Moran-Gilad from the Israeli Ministry of Health, who has been the driving force behind the issue and joint publication of four papers from Israel.
We hope our readers will enjoy the articles and the editorial by D Heymann and Q Ahmed, which shed light on some of the problems that need to be tackled in the end phase of polio eradication - a goal that is within reach.

\section{References}

1. The Global Polio Eradication Initiative. Data and Monitoring. Polio eradication and endgame timeline. Geneva: World Health Organization. [Accessed 18 Feb 2014]. Available from: http://www.polioeradication.org/Dataandmonitoring/ Polioeradicationtargets.aspx

2. World Health Organization (WHO). Immunization, Vaccines and Biologicals. Monitoring and surveillance. Polio Case Count. Geneva: WHO. [Accessed 18 Feb 2014]. Available from: http:// www.who.int/vaccines/immunization_monitoring/en/diseases/ poliomyelitis/case_count.cfm

3. Ahmed QA ,Nishtar S, Memish ZA. Poliomyelitis in Pakistan: time for the Muslim world to step in. Lancet. 2013;381(9877):1521-3. http://dx.doi.org/10.1016/ S0140-6736(13)60764-3

4. AFP. Bomb-kills-policeman-as-polio-vaccination-targeted-inpeshawar. Published: 16 February 2014. Tribune. [Accessed 18 Feb 2014]. Available from: http://tribune.com.pk/ story/672503/bomb-kills-policeman-as-polio-vaccinationtargeted-in-peshawar/

5. World Health Organization (WHO). Disease outbreak news. Polio in the Syrian Arab Republic. 29 Oct 2013. Geneva: WHO. [Accessed 18 Feb 2014]. Available from: http://www.who.int/ csr/don/2013_10_29/en/index.html

6. World Health Organization (WHO). Disease outbreak news. Poliovirus detected from environmental samples in Israel. 3 Jun 2013. Geneva: WHO. [Accessed 18 Feb 2014]. Available from: http://www.who.int/entity/csr/don/2013_06_03/en/index.html

7. World Health Organization (WHO). WHO Director-General celebrates polio-free India. Address at the "India celebrates triumph over polio" event. New Delhi, India. 11 Feb 2014. Geneva: WHO. [Accessed 18 Feb 2014]. Available from: http:// www.who.int/dg/speeches/2014/india-polio-free/en/

8. The Global Polio Eradication Initiative. Data and Monitoring. Polio this week. Geneva: World Health Organization. [Accessed 18 Feb 2014]. Available from: http://www.polioeradication.org/ Dataandmonitoring/Poliothisweek.aspx 